\section{Rothman - en merkevare i epidemiologi}

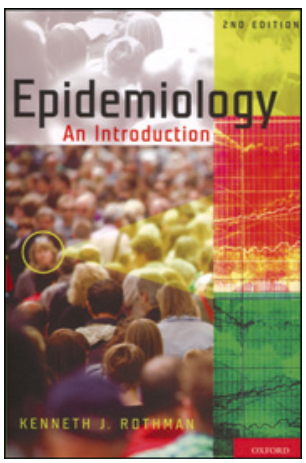

Kenneth J. Rothman

\section{Epidemiology}

An introduction. 2. utg. $268 \mathrm{~s}$, tab, ill. Oxford: Oxford University Press, 2012. Pris GBP 25 ISBN 978-0-19-975455-7

$\AA$ anmelde Rothmans introduksjonsbok i epidemiologi har visse fellestrekk med hvordan jeg forestiller meg det er å anmelde en ny iPhone. De er begge merkevareprodukter som har stått seg godt og lenge i markedet. Boken er, i tråd med tittelen, en introduksjonsbok i sentrale begreper i faget. Ifølge vaskeseddelen er målet å føre oss gjennom tåkeheimen og lyse opp de fundamentale begrepene. Denne utgivelsen har, på tross av et begrenset antall sider, dybde nok til å fungere godt som introduksjon og referansebok hos mange, også de som har en viss bakgrunnskunnskap i faget. Den arketypiske leseren kunne vært medisinstudent, men jeg vil likevel tro at han/hun er i starten av et forskerutdanningsløp. Begreper som risiko i ulike varianter, studieopplegg, populasjon, feilkilder og så videre er alle sentrale deler av akademisk medisin. Så boken kan godt plasseres ved siden av introduksjonsbøker i fysiologi, anatomi og lignende basale fag på legekontoret.

Det er 12 kapitler. Og de vesentlige elementene som går igjen i andre tilsvarende lærebøker i epidemiologi, kommer også her: definisjon av sykdomsårsaker, hvordan man måler sykdomsforekomst og effekter, type studieopplegg og feilkilder. Rothmans styrke er som pedagog. Dette kommer til uttrykk flere steder i fine figurer som fanger vanskelige begreper og sammenhenger på en bra måte. P-verdifunksjon er et eksempel på det, og det er kanskje særlig $i$ overgangen når det gjelder statistikk at boken er opplysende.

Så hvor ligger svakhetene? Den største synlige svakheten er når Rothman skal plassere begrepene i en faglig sammenheng, for eksempel vitenskapsteoretisk i kapitlene om årsaker og historie hvor han ramser opp (selektivt) kjente og mindre kjente navn uten å diskutere og plassere dem i en historisk rammefortelling. Vår forståelse av sykdomsårsaker er ikke historieløs. Den har forandret seg i takt med rådende hovedfortellinger i samfunnet og vitenskapen for øvrig. Og spørsmål om årsak til sykdom som innfallsport til epidemiologisk teori blir litt fattig berørt. Han refererer pliktskyldig til store vitenskapsteoretikere utenfor faget, som Kuhn og Feyerabend, men unnlater å nevne debatter om nettopp teori innad i faget.

Ikke alle introduksjonsbøker i epidemiologi er like grundige $\mathrm{i} a ̊$ forankre faget i teoretiske perspektiver (1). Selv om bøkene deres for lengst er blitt klassikere, gjorde Susser og Morris til en viss grad det $(2,3)$. Det samme gjelder for Bhopal i dag (4). Det er kanskje for mye forlangt å kreve alt dette i en introduksjonsbok. Skal man ha en grundig innføring i tekniske begreper, er Rothman uovertruffen. Og man kommer for så vidt langt med det.

\section{Øyvind Næss}

Nasjonalt folkehelseinstitutt

Oslo

\section{Litteratur}

1. Krieger N. Epidemiology and the web of causation: has anyone seen the spider? Soc Sci Med 1994; 39: 887-903

2. Susser M. Causal thinking in the health sciences. New York, NY: Oxford University Press, 1973.

3. Morris JN. Uses of epidemiology $3^{\text {rd }}$ edition. Edinburgh: Churchill Livingstone, 1975.

4. Bhopal R. Concepts of Epidemiology. An integrated introduction to the ideas, theories, principles and methods of epidemiology. New York, NY: Oxford University Press, 2002.

\section{Seksuelle konflikter mellom mann og kvinne}

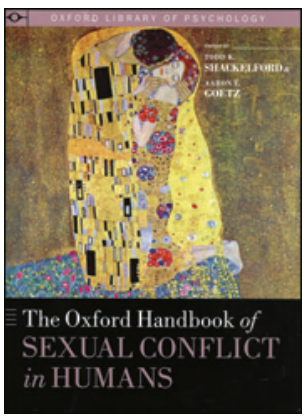

Todd K. Shackelford, Aaron T. Goetz, red The Oxford handbook of sexual conflict in humans

349 s, tab, ill. Oxford: Oxford University Press, 2012. Pris GBP 85

ISBN 978-0-19-539670-6

Målet til Oxford Library of Psychology er å produsere høyaktuelle bøker innen psykologiens mange områder. Denne utgivelsen har en meget stor bredde, og forfatterne går dypt inn i de ulike seksuelle konfliktene mellom mann og kvinne. Boken vil derfor være aktuell for en rekke ulike fagområder innen psykologien, men også for andre kliniske fag som gynekologi, urologi og sexologi.

The Oxford handbook of sexual conflict in humans er den første boken i sitt slag som samler dagens viten, både teoretisk og empirisk, om seksuelle konflikter mellom mann og kvinne. Forfatterne har samarbeidet med 42 forskere innen psykologi og antropologi fra hele verden, og boken har derfor en imponerende referanseliste etter hvert kapittel. Det er fem hoveddeler, og det er oversiktlig og lett å finne ulike temaer av interesse. Boken kan derfor leses etter ønsket tema og ikke nødvendigvis fra perm til perm. Flere illustrasjoner hadde vært ønskelig.

I introduksjonsdelen tar bidragsyterne for seg teorier og forskning innen seksuelle konflikter. Deretter følger egne deler som omhandler seksuelle konflikter før, under og etter samleie og eventuell befruktning. En rekke aspekter omtales grundig. Seksuell makt, sjalusi, partnervold og drap får egne omtaler. Menstruasjonssyklus, kvinnelig orgasme, sædinnhold og forholdet mellom ejakulat og kvinnens forplantningsorganer får en grundig gjennomgang. I disse kapitlene er det mye nyttig og ny viten som burde fenge interessen hos en rekke ulike fagpersoner.

En egen del omhandler seksuelle konflikter etter fødsel, både kvinnens og mannens spesifikke problemer, men også de problemene som oppstår i samspillet og samlivet mellom partnere etter barnefødsel. Til slutt diskuterer forfatterne hvordan seksuelle konflikter kan påvirkes av kulturelle, politiske og religiøse forhold.

Boken er absolutt leseverdig og meget innholdsrik og kan fungere som et oppslagsverk. Den er spekket med referanser og er preget av at innholdet er grundig validert. Det er en bok for dem som interesserer seg for seksuelle problemstillinger, og som ønsker forskningsbaserte fakta om dette spesielle emnet.

Morten Andersen

Moelv Spesialistsenter 